\title{
Information System Management of Posyandu Activities Based on Web-Based Integrated Line Messenger at Posyandu Anggrek II, Purwosari Village
}

\author{
Nugroho Dwi Saputro ${ }^{1}$, Rahmat Robi Waliyansyah ${ }^{2 *}$, Mega Novita ${ }^{3}$, Vina Azhari \\ Putri $^{4}$
}

${ }^{1,2,3,4}$ Universitas PGRI Semarang

*Corresponding author. Email: rahmat.robi.waliyansyah@upgris.ac.id

\begin{abstract}
At this time posyandu information reports are still in manual form which are still written in different books, so their use is relatively inefficient and the archives of posyandu data reports are piling up at the posyandu head. Delivery of information on Posyandu schedules and regular monthly counseling still uses mosque speakers to convey information to the public in the Anggrek II Posyandu environment. The author took the initiative to create an integrated web-based Posyandu activity management information system, Line Messenger, to facilitate the management of Posyandu data and information in the Anggrek II Posyandu environment. The method used in this research is a prototyping method using the PHP and MySQL programming languages. From the results of the User Acceptance Testing test, it shows 92.5\%, meaning that this system is suitable for use for integrated service posts (posyandu), while the results of the Blackbox Testing test show $100 \%$ which means it is very feasible to use. From this research, it can be concluded that this webbased Posyandu activity management information system can be useful for agencies and the community.
\end{abstract}

Keywords: Web, Line Messenger, Prototyping

\section{INTRODUCTION}

Integrated Service Post (Posyandu) is a community service center whose main activity is serving the health of mothers and babies who play an important role in the general public[1]. The role of Posyandu is a form of community participation that has a very big meaning for maternal and child health in health development with the main target being infants, toddlers and pregnant women[2]. One of the efforts to fulfill basic services which include maternal and child health $(\mathrm{MCH})$, immunization, nutrition improvement and a healthy environment is through the implementation of posyandu activities[3].

Posyandu implementation is carried out once a month, posyandu is carried out by cadres and midwives to help check health for the community, especially mothers and children. First the child is weighed and measured for height first assisted by the cadre, the cadre will record the child's data on the card for health (KMS)[4]. Card Towards Healthy (KMS) is a card that contains a child's growth curve based on the weight index according to age which is differentiated by gender[5]. As for pregnant women, namely weighing and giving vitamins, the cadres are tasked with recording the health data of the pregnant women in a book managed by the cadres. Each village has several posyandu posts[6].

One example is the Anggrek II Posyandu in Purwosari Village, the Anggrek II Posyandu is a form of one of the village work programs carried out by POKJA IV in Family Welfare Development activities or called PKK [7]. Posyandu in Purwosari Village is held once a month on the second week in Purwosari Village. The Angreek II Posyandu was held at the house of Mr. Bayan Bari, which is located at Hamlet Sambikerep, Purwosari Village, Tlogowungu District, Pati Regency.

Based on interviews with the head of the Anggrek Posyandu II and the Coordinator of the Cadre of the Anggrek Posyandu II in Purwosari Village, some information was obtained regarding the problems that exist in the Posyandu Activity Management Information System [8]. At this time the posyandu data is still in manual form which is still written in different books, so 
its use is relatively inefficient and the archives of posyandu data reports are piling up at the posyandu head[9]. Delivery of information on Posyandu schedules and regular monthly counseling still uses mosque speakers to convey information to the public in the Anggrek II Posyandu environment. Therefore, a system is needed to make it easier to provide information and manage Posyandu data for the community, especially women in Purwosari Village.

\section{METHOD}

In this study, the stages carried out by researchers are to facilitate the conduct of research. This system research uses line messenger because line messenger can provide notifications on Broadcast Chat so that information can be shared with all contacts[10]. Line Bot Api has an easier and simpler architecture, the official SDK release supports five programming languages (Java, PHP, and Perl5)[11]. Activities in software development using line messenger are focused on developing models using the Unified Model Language (UML), because they use object-oriented concepts[12]. The following are the hardware and software requirements used in the research, namely[9]:

1. Hardware : Laptops with windows (10), 8GB laptop RAM, $100 \mathrm{Mb}$. computer disk space, Android 8.1 Oreo with Color OS interface.

2. Software: The server used by XAMPP with the PHP version \& Browsers used by Google Chrome Desktop / Android and Mozilla Firefox.

In designing an integrated web-based posyandu activity management information system, line messenger, there are 5 stages in system development using a prototyping model[10].

1. Needs Collection

The collection of these needs is carried out in 2 stages, namely observation can be seen by observing directly what is happening at the research site. Meanwhile, interviews were conducted with related parties, namely the head of the Posyandu Anggrek II.

2. Building Prototyping

Build prototyping by making designs that focus on presenting the system by making Unified Model Language (UML) designs, namely from use case diagrams, activity diagrams, sequence diagrams, and class diagrams.

3. Prototyping Evaluation

This evaluation is carried out to determine the results of whether the system is in accordance with the wishes of the user or not. Users have tried the integrated web-based Posyandu activity management information system, that the system can be used properly and can make it easier for users to manage posyandu data.

4. Encoding System
The coding of this system is done if the agreed prototyping will be translated into programming languages, namely PHP and MySQL.

5. Testing System

In this system testing stage, after the system has been successfully created, the next step is system testing. System testing is done by user acceptance testing and blackbox testing. User acceptance testing is carried out with system users starting from admins, leaders, and users. While blackbox testing is carried out by experts in the system.

The research flow is a chronological arrangement carried out by a researcher in his research work. The research flow is a continuous methodological structure or relationship[13]. The goal is to keep the focus on the problem and make it easier to achieve the research objectives[14]. It is also hoped that the linkage and sustainability can be maintained at each stage of the research[15]. The following figure 1 is the structure of the research flow that the author designed:

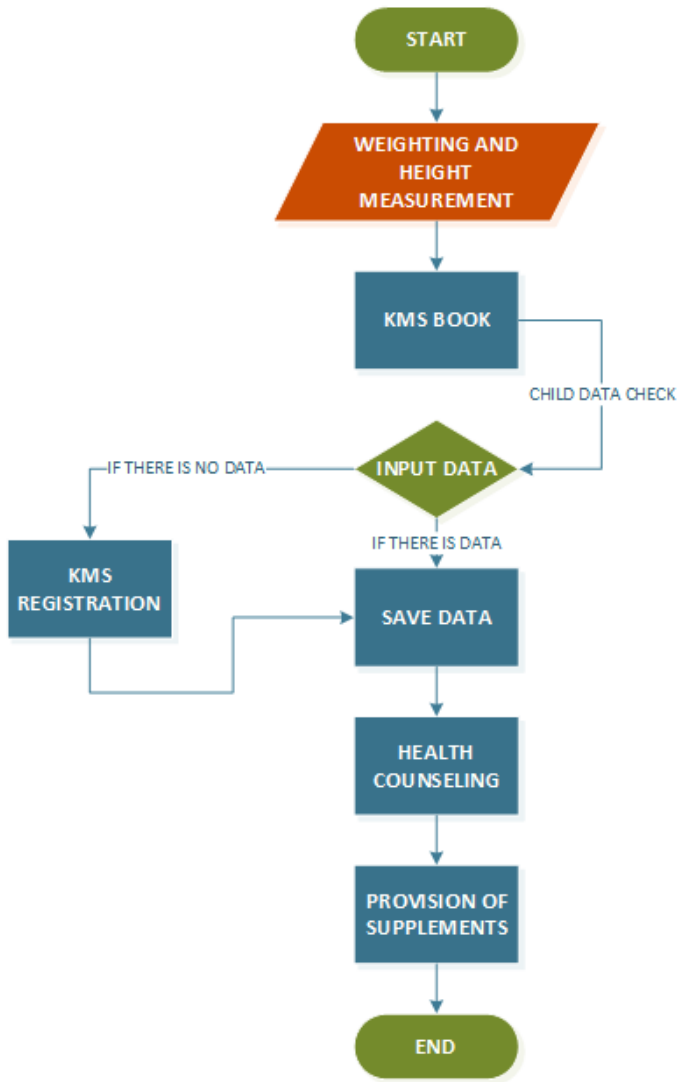

Figure 1. Posyandu Activity Management Information System Flowchart

Figure 1 shows the Posyandu Activity Management Information System Flowchart proposed by the researcher. In the data structure of the posyandu information system, starting from start or login, then there is a home page for the initial display of the system, posyandu schedule, registration of infants and toddlers, 
registration of pregnant women, child data, maternal data and data counseling[16]. Furthermore, weighing and measuring height, then the cadres fill out the KMS book, namely the card book to be healthy, if there is data, the cadres enter the data into the information system[17]. However, if there is no data, the admin must register KMS or check the data again to find out whether the data has been filled in or not[18]. In addition to weighing and measuring height data, there are also other sequences such as health education or information sharing to mothers carried out by health experts[19]. Then after everything is done, next is the provision of supplements to pregnant women and children[20].

\section{RESULTS AND DISCUSSION}

In the results of this research and discussion, we will discuss the stages carried out by the author in research using a frame of mind that has 5 stages[21], namely, first, gathering needs which discusses the identification of all needs carried out by observation and interviews. Second, building prototyping is the stage of making a temporary design that focuses on presenting it to users by making a Unified Model Language (UML) design. Third, Prototyping Evaluation is the stage of identifying whether the system that has been built is in accordance with the wishes of the user or not[22]. If it is appropriate, then the next step will be taken. But if not, the system is revised by repeating the previous steps. The next step is to code the system in this stage the agreed prototyping is translated into appropriate programming languages such as xampp, MySQL and php[23]. Next is Testing the System after the system has become a ready-to-use software, then the Testing process is carried out. This test is done by User Acceptance Testing and Black box Testing.

Prototyping evaluation is carried out by the user, whether the prototyping that has been built is in accordance with the wishes of the customer or not[24]. If it is appropriate, then the next step will be taken. But if not, the prototyping is revised by repeating the previous steps[25].

The following are some display results from the integrated web-based Posyandu activity management information system[26], which can be seen in Figure 2 to 13.

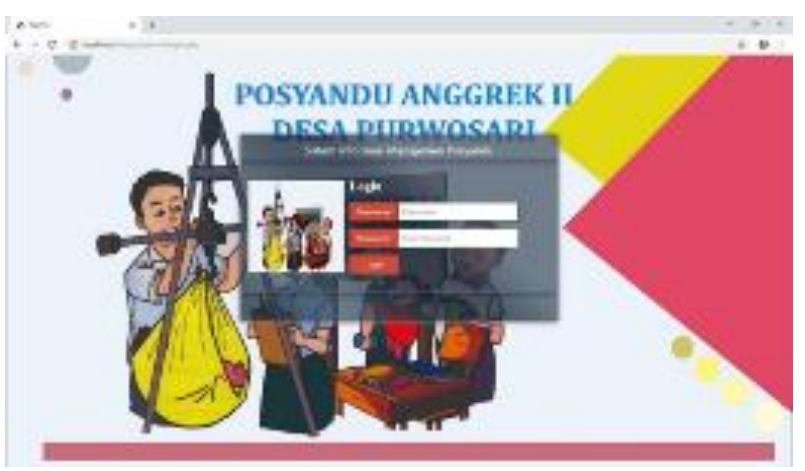

Figure 2. Login System Display

Figure 2 shows the login system display on the Posyandu Anggrek II management information system which contains a username and password and a login button to enter the system.

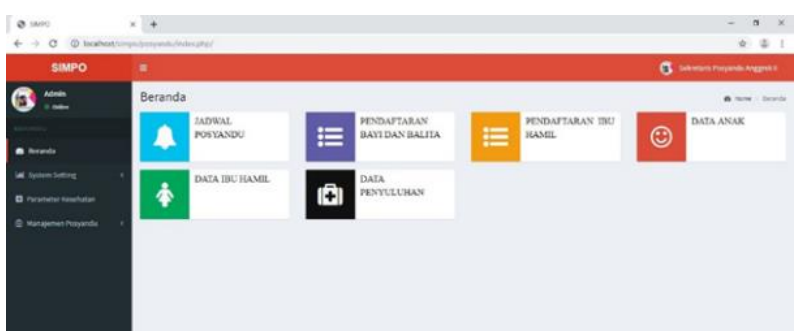

Figure 3. Home System View

Figure 3 describes the appearance of the homepage system on the posyandu management information system after a successful login. This homepage system contains posyandu schedules, registration of infants and toddlers, registration of pregnant women, child data, data for pregnant women, counseling data and also admin system settings.

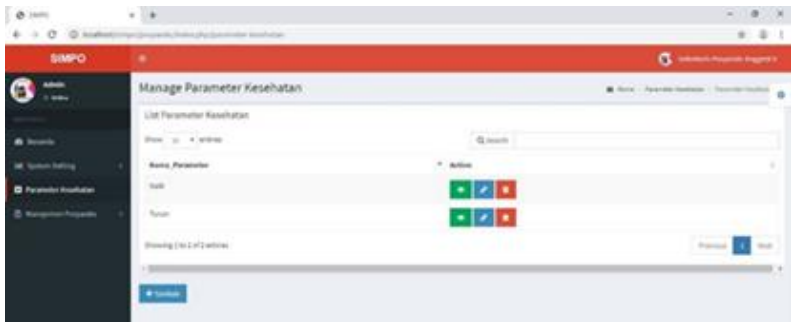

Figure 4. Health Parameters System Display

Figure 4 shows the appearance of the health parameter input system. This health parameter system functions as one of the input parameters in the child's data.

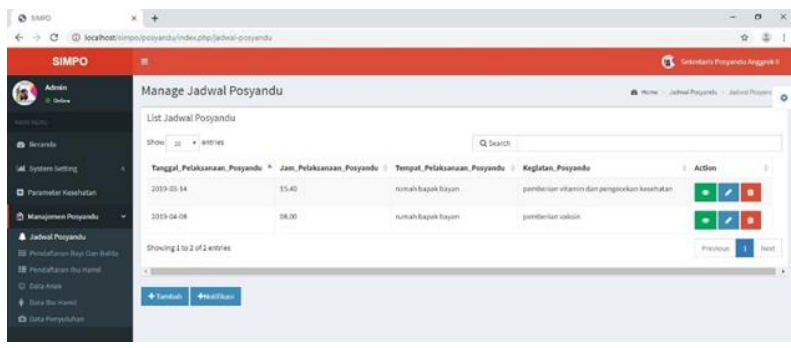

Figure 5. Posyandu Schedule System Display 
Figure 5 shows the appearance of the posyandu schedule system which contains the date of posyandu implementation, posyandu implementation hours, posyandu implementation locations, posyandu activities and several action buttons starting from the report print, edit, delete, add and notification buttons.

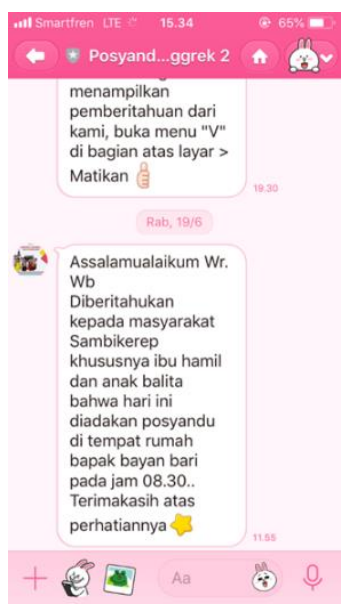

Figure 6. Posyandu Schedule Notification System Display

Figure 6 shows the appearance of the posyandu schedule notification system for users that has been shared by the admin. Notification with the posyandu schedule line application model for users to convey information on the posyandu schedule that is being held at the posyandu.

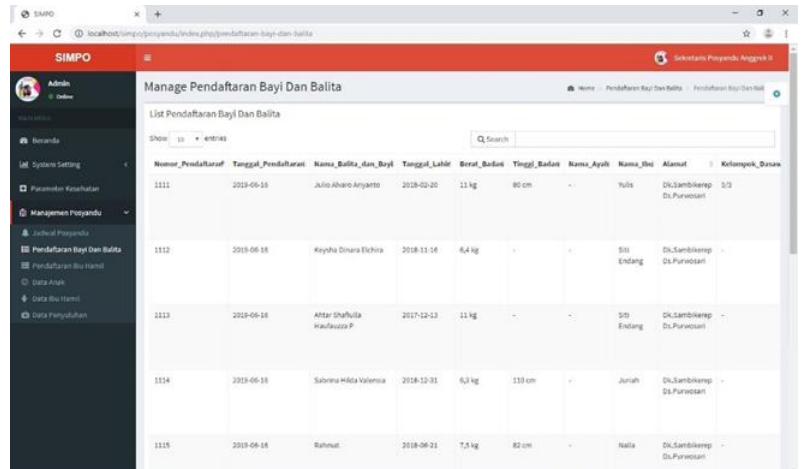

Figure 7. Baby and Toddler Registration System Display

Figure 7 shows the display of the baby and toddler registration system which contains the registration number, registration date, toddler and baby names, date of birth, weight, height, father's name, mother's name, address, dasawisma group, description and several actions starting from the buttons. print reports, edit, delete and add.

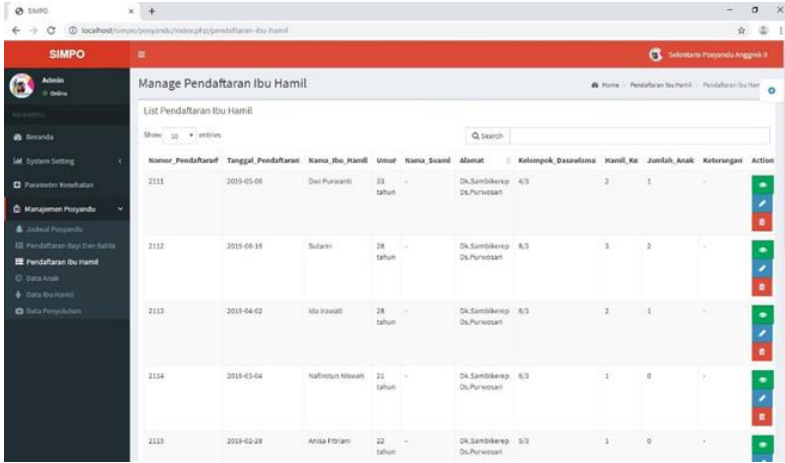

Figure 8. Maternity Registration System Display

Figure 8 shows the display of the registration system for pregnant women which contains the registration number, registration date, name of pregnant women, age, husband's name, address, dasawisma group, pregnant to, number of children, description and several actions starting from the report print button, edit, remove and add.

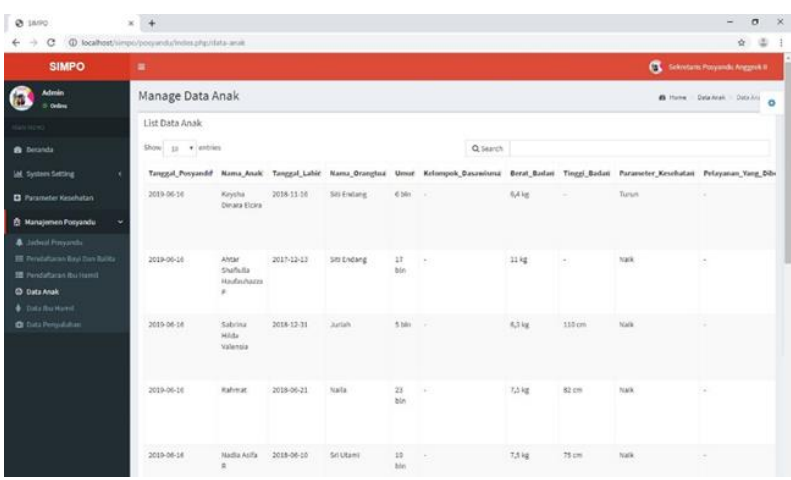

Figure 9. Child Data System Display

Figure 9 shows the display of the child's data system which contains the date of the posyandu, child's name, date of birth, parent's name, age, dasawisma group, weight, height, health parameters, services provided, immunization, notes and several actions ranging from report print, edit, delete and add buttons.

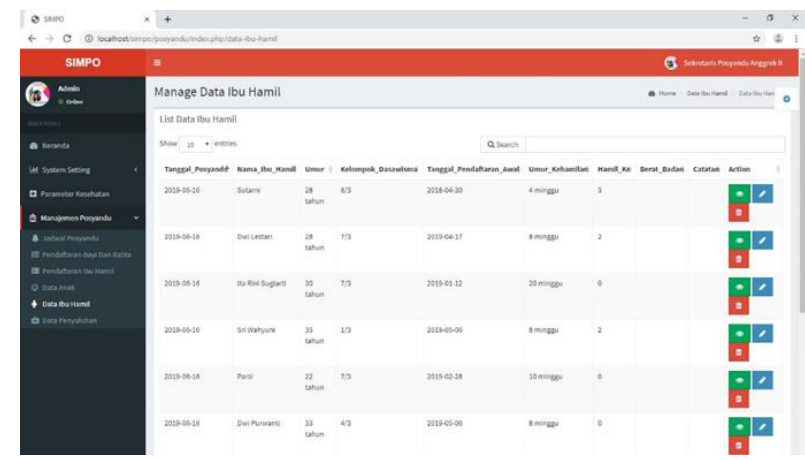

Figure 10. Maternity Data System Display

Figure 10 shows the display of the data system for pregnant women which contains the date of the posyandu, the name of the pregnant woman, the age, the dasawisma group, the registration date, gestational age, pregnant to, weight, notes and several actions starting from the report print button, edit, delete and added. 


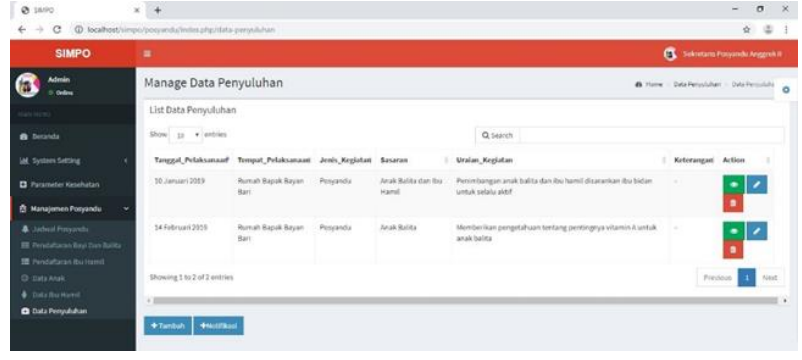

Figure 11. Extension Data System Display

Figure 11 shows the display of the extension data system which contains the date of implementation, place of implementation, types of activities, targets, descriptions of activities, descriptions and several actions starting from the report print button, edit, delete, add and notification.

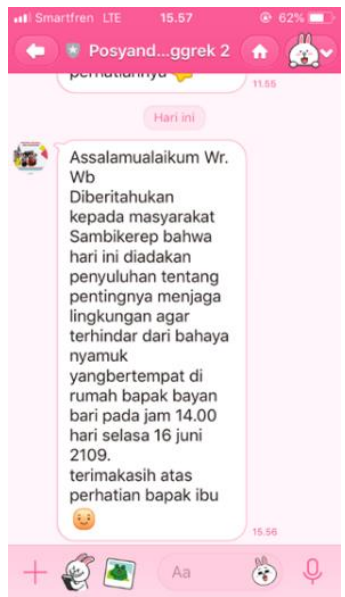

Figure 12. Extension Notification System Display

Figure 12 shows the display of extension information notifications that have been shared by the admin through the line application.

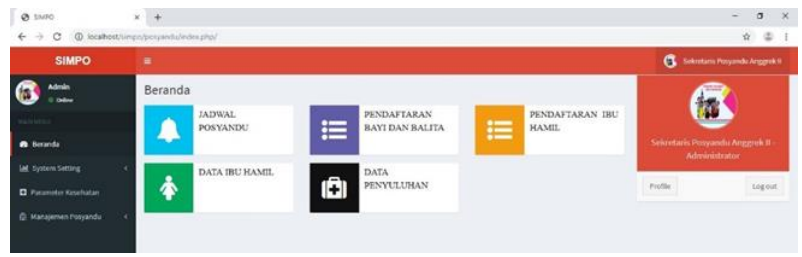

Figure 13. Display System Logout

Figure 13 shows the display of the system logging out or logging out of the system. So the user will select the menu icon in the upper right corner after the system is clicked it will appear as shown above.

At this stage of testing is done using the Chrome browser and several other browsers. This test was conducted to evaluate the design of an integrated webbased Posyandu activity management information system with line messenger. The testing methods used in this system are User Acceptance Testing and Black Box Testing[27].

User acceptance is carried out to find out about user opinions for the integrated web-based Posyandu activity management information system in terms of line messenger in terms of the benefits and usability of the system[28]. User acceptance is carried out on 3 respondents. The results of the user acceptance test can be seen in the attachment. The following explains the score of each statement and the percentage of system testing is:

$$
\begin{aligned}
& 1=\text { Strongly disagree } \\
& 2=\text { Disagree } \\
& 3=\text { Uncertain } \\
& 4=\text { Agree } \\
& 5=\text { Strongly Agree }
\end{aligned}
$$

To find out whether the posyandu management information system is feasible to use based on the following criteria:

$$
\begin{aligned}
& 100 \%=\text { Very Eligible } \\
& 80 \%-99 \%=\text { Eligible } \\
& 70 \%-79 \%=\text { Fairly Decent } \\
& 60 \%-69 \%=\text { Not Eligible } \\
& <59 \%=\text { Very Unfit }
\end{aligned}
$$

Here are the questions that were at the time of black box testing:

1) Is the SIMPO system useful for admins, leaders, and users in terms of productivity?

2) Is the SIMPO system useful for admins, leaders, and users in terms of performance?

3) Is the SIMPO system useful for admins, leaders, and users in terms of effectiveness?

4) Is the SIMPO system useful for admins, leaders, and users in terms of usability?

5) Is the SIMPO system easy to understand?

6) Is the SIMPO system easy to use?

7) Is the presentation of the output appropriate?

8) Is the information clear?

The following are the results of user acceptance testing which are shown in table 1.

Table 1. User Acceptance Testing Results

\begin{tabular}{|c|c|c|c|}
\hline \multirow{2}{*}{ Question } & \multicolumn{3}{|c|}{ Respondents and Score } \\
\cline { 2 - 4 } & Admin & Leader & User \\
\hline 1 & 4 & 4 & 5 \\
\hline 2 & 5 & 4 & 4 \\
\hline 3 & 5 & 5 & 5 \\
\hline 4 & 5 & 5 & 5 \\
\hline 5 & 5 & 5 & 4 \\
\hline 6 & 4 & 5 & 5 \\
\hline 7 & 5 & 4 & 4 \\
\hline 8 & 5 & 4 & 5 \\
\hline Total score & 38 & 36 & 37 \\
\hline Percentage & $95 \%$ & $90 \%$ & $92.5 \%$ \\
\hline Total & \multicolumn{3}{|c}{$92.5 \%$} \\
\hline
\end{tabular}

Based on the results of the tests that have been carried out, it can be seen that the percentage achieved is as follows:

$$
\text { Reached } \quad=11 / 11 \times 100 \%=100 \%
$$

Filed $=0 / 10 \times 100 \%=0 \%$ 
So from the results of the Black Box Testing test obtained with a percentage result of $100 \%$ it is feasible to use.

This integrated web-based Posyandu activity management information system was created because posyandu information reports are still in manual form which are still written in different books, so their use is relatively inefficient and the archives of posyandu information reports are piling up at the posyandu head. Delivery of information on Posyandu schedules and regular monthly counseling still uses mosque speakers to convey information to the public in the Anggrek II Posyandu environment. Therefore, the researcher created a web-based integrated Posyandu activity management information system using line messenger using the prototyping research method. This method was chosen because in this prototyping method it is very suitable to be applied to high-risk conditions where the problems are not well structured, there are fluctuations in user needs that change from time to time, interaction with users is an absolute requirement and the available time is very limited so that it needs an immediate solution. The integrated web-based Posyandu activity management information system is good for use at the Anggrek II Posyandu in Purwosari Village.

This system is made using PHP and MySQL programming languages with Xammp and SublimeText tools. This system has 3 users, namely admin, leadership and users as recipients of line messenger notifications. In this system, the admin is a cadre as the secretary of the Orchid Posyandu II who is in charge of inputting the data in the Orchid II Posyandu. The leader here is the head of the Posyandu Anggrek II who monitors the SIMPO operation. While the user is the community, especially the women in the Posyandu Anggrek II, Purwosari Village. This system contains health parameters as options or data input in the child's data, then the posyandu schedule is also available as an archive and information delivery of posyandu being held. thirds, there is the registration of infants and toddlers as a registration menu for infants and toddlers before conducting a health check. Fourth, there is the registration of pregnant women, namely the registration menu for pregnant women before carrying out the examination. Furthermore, there is data on children and data on pregnant women as report archives. The last is the extension data as well as archival data and also the delivery of information to the people of Purwosari Village, especially mothers, that counseling will be held.

Testing on the system is carried out with two types of testing, namely user acceptance testing and black box testing. Testing User Acceptance Test, carried out to test the suitability of the system with user needs. Where for user acceptance testing by admins, leaders and users of this system is proven to be in accordance with the needs with a percentage of $92.5 \%$.
In black box testing is done to test the way the system is used. In these two tests it is proven that this system is feasible to use with a percentage of $100 \%$.

\section{CONCLUSION}

The conclusions of this study are as follows:

1. This integrated line messenger web-based Posyandu activity management information system was built using the PHP and MySQL programming languages using the prototyping method.

2. Based on User Acceptance Tests conducted on 3 test respondents. The integrated web-based posyandu activity management information system has a percentage of $92.5 \%$. While the Black Box test gets a percentage of $100 \%$, it means that the system that has been made is suitable for use.

3. With a web-based integrated Posyandu activity management information system, line messenger can make it easier for cadres to manage data and information at the Anggrek II Posyandu.

\section{REFERENCES}

[1] H. Pujianto and S. Rokhmah, "Analysis of "EPatient UNS" Application System for Online Registration of UNS Hospital Patients," int. J. Comput. inf. syst., vol. 02, no. 01, pp. 10-13, 2021.

[2] A. Boiko, V. Shendryk, and O. Boiko, "Information systems for supply chain management: Uncertainties, risks and cyber security," Procedia Comput. science., vol. 149, pp. 65-70, 2019.

[3] C. Wang et al., "Efficacy of computer-based endoscope cleaning and disinfection using a hospital management information system," Am. J. Infects. Control, vol. 44, no. 8, pp. e141-e143, 2016.

[4] SS Gilbert et al., "The impact of an integrated electronic immunization registry and logistics management information system (EIR-eLMIS) on vaccine availability in three regions in Tanzania: A pre-post and time-series analysis," Vaccine, vol. 38, no. 3, pp. 562-569, 2020.

[5] M. Savitsky et al., "Recording information on protein complexes in an information management system," J. Struct. Biol., vol. 175, no. 2, pp. 224-229, 2011.

[6] J. Woollen, R. Scott, R. Lucero, and S. Bakken, "A semi-automated approach for analyzing collages to inform the design of a family health 
information management system for Hispanic dementia caregivers," J. Biomed. Inform., vol. 95, 2019.

[7] A. Ardila et al., "XRepo - Towards an information system for prognostics and health management analysis," Procedia Manuf., vol. 42, no. 2019, pp. 146-153, 2020.

[8] D. Wang et al., "A novel application of educational management information system based on micro frontends," Procedia Comput. Sci., vol. 176, pp. 1567-1576, 2020.

[9] SH Afrizal, PW Handayani, AN Hidayanto, T. Eryando, M. Budiharsana, and E. Martha, "Barriers and challenges to Primary Health Care Information System (PHCIS) adoption from health management perspective: A qualitative study," Informatics Med. Unlocked, vol. 17, no. May, p. 100198, 2019.

[10] H. Berndt and M. Herczeg, "An Integrated Information and Decision-Support System for the Management of Mass Casualty Incidents," IFAC-PapersOnLine, vol. 52, no. 19, pp. 199204, 2019.

[11] S. Jacobsson, PO Arnäs, and G. Stefansson, "Automatic information exchange between interoperable information systems: Potential improvement of access management in a seaport terminal," res. Transp. Buses. Manag., vol. 35, no. March, p. 100429, 2020.

[12] M. Kunath and H. Winkler, "Usability of information systems to support decision making in the order management process," Procedia CIRP, vol. 81, pp. 322-327, 2019.

[13] A. Deharja and MW Santi, "The evaluation of hospital information system management based on hot-fit model at rsu $\mathrm{dr}$. h . Koesnadi Bondowoso 2018,"Proceedings B. 1st Int. Food Agric., pp. 486-490, 2018.

[14] E. Syam, "Design of Integrated Student and Lecturer Data Management Information System," It J. Res. Dev., vol. 2, no. 2, pp. 45-51, 2018.

[15] M. Cai, M. Li, and W. Cao, "Blockchain based Data Distribution and Traceability Framework in the Electric Information Management System," Procedia Comput. science,, vol. 162, 2019, pp. 82-87, 2019.

[16] T. Saha, RH Bhuiya, ZU Masum, MR Islam, and JA Chowdhury, "Hospital Pharmacy Management System and Future Development Approaches in Bangladeshi Hospital," Bangladesh Pharm. J., vol. 20, no. 2, pp. 180187, 2018.
[17] A. Seth, A. John Coffie, A. Richard, and S. AduYeboah Stephen, "Hospital Administration Management Technology Adoption; A Theoretical Test of Technology Acceptance Model and Theory of Planned Behavior on HAMT Adoption,"Am. J. Public Healing. res., vol. 7, no. 1, pp. 21-26, 2019.

[18] D. Demirel, "Hospital Management Information Systems in Health Sector and Development in Turkey Journal of Current Researches on Health Sector Hospital Management Information Systems in Health Sector and Development in Turkey," J. Curr. res. heal. Sect., vol. 7, no. 1, pp. 37-50, 2017.

[19] M. Ali Akram, M. Iqbal Mahmud, S. Riad Bin Ashraf, S. Awal, and S. Talapatra, "Enhancing the Healthcare Service Using Quality Function Deployment and Database Management System in the Outpatient Department of a Government Hospital of Bangladesh," int. res. J. Eng. Technol., vol. 5, no. 4, pp. 2022-2029, 2018.

[20] ED Kim, KKY Kuan, MR Vaghasiya, N. Gunja, J. Penm, and SK Poon, "Evaluating user satisfaction and organizational benefits of electronic medication management system in an Australian hospital," Proc. 28th Australia. conf. inf. syst. ACIS 2017, 2017.

[21] MG Nkanata, EO Makori, and G. Irura, "Comparative Analysis of Hospital Information Management Systems among Healthcare Workers in Two Selected Hospitals in Kenya," Libra. Philos. practice., no. December, p. 1, 2018 .

[22] S. Catellani, L. Bonato, S. Huber, and E. Mezzetti, "Challenges in the implementation of MrsP," Lect. Notes Comput. science. (including Subser. Lect. Notes Artif. Intell. Lect. Notes Bioinformatics), vol. 9111, no. 214, pp. 179-195, 2015.

[23] A. Setiawan and AI Purnamasari, "Development of Smart Homes With ESP32 Microcontrollers and MC-38 Door Magnetic Switch Sensors Based on Internet of Things (IoT) to Improve Early Detection of Residential Security," $J$. RESTI (System Engineering and Information Technology), vol. 3, no. 3, pp. 451-457, 2019.

[24] YI Mukti, "Web-Based School Asset Management Information System," in Indonesian Journal of Business Intelligence (IJUBI), 2019, vol. 1, no. 2, pp. 632-638.

[25] AN Cahyanti and BE Purnama, "Management Information System Development Pakis Baru Nawangan Health Center," Speed J. - Research Center. eng. and Education, vol. 4, no. 4, pp. 1721,2017 
[26] NK Wardhani and MTA Aziz, "Web-Based Human Resource Management Information System (Case Study: Pt. Klik Teknologi Indonesia)," J. TECHNO Nusa Mandiri, vol. 15, no. 2, pp. 145-152, 2018.

[27] D. Ulinafiah and NA Wiyani, "Creation of Excellent Service Through the Implementation of Management Information Systems in Other
Purwokerto Libraries," re-JIEM (Research J. Islam. Educ. Manag., vol. 2, no. 2, pp. 223-239, 2019.

[28] Happy, D. Satria, and H. Ahmadian, "Design of an Android-Based Disaster Victim Data Management Information System," J. Manaj. and Accounts., vol. 3, no. 2, pp. 22-30, 2017. 